\title{
Malignant Epithelioid Schwannoma of the Oral Cavity in a Cat
}

\author{
Hassadin BOONSRIROJ ${ }^{1)}$, Kazunori KIMITSUKI ${ }^{1)}$, Tetsuya AKAGI ${ }^{2)}$ and Chun-Ho PARK ${ }^{1) *}$ \\ 1) Department of Veterinary Pathology, School of Veterinary Medicine, Kitasato University, 23-35-1, Higashi, Towada, Aomori 034-8628, \\ Japan \\ 2) Akagi Animal Hospital, 1900, Takao, Niimi, Okayama 718-0003, Japan
}

(Received 29 January 2014/Accepted 1 March 2014/Published online in J-STAGE 17 March 2014)

\begin{abstract}
A malignant epithelioid schwannoma of the oral cavity was diagnosed in an 8-year-old domestic short-hair cat. The mass was located in the gingiva of the upper left premolar to molar region and showed multinodular growth patterns. The mass comprised epithelioid cells arranged in densely packed sheets. Tumor cells had large, round to oval nuclei with prominent nucleoli and an abundant eosinophilic cytoplasm. Immunohistochemically, most of the tumor cells were positive for S-100 protein, glial fibrillary acidic protein and vimentin, but all lacked melanoma-associated antigen and muscle and neuroendocrine markers. Stains for type IV collagen showed linear immunoreactivity around single cells and groups of cells. Ultrastructurally, tumor cells were separated by a well-defined basement membrane, and interdigitating cell processes were observed. To our knowledge, this is the first report of feline malignant epithelioid schwannoma. KEY WORDS: feline, malignant epithelioid schwannoma, oral cavity.
\end{abstract}

doi: 10.1292/jvms.14-0057; J. Vet. Med. Sci. 76(6): 927-930, 2014

Schwannomas (peripheral nerve sheath tumors) are common tumors of the peripheral nervous system of domestic animals and have been reported in dogs [3], cats [14], horses [13] and cows [15]. By contrast, malignant epithelioid schwannoma is an unusual variant of peripheral nerve sheath tumor that closely resembles carcinoma or melanoma because the tumor comprises exclusively Schwann cells with a polygonal epithelioid appearance $[1,8]$. In humans, this tumor was reported to originate from peripheral nerves including the sciatic, facial, digital and antebrachial cutaneous nerves [17]. In domestic animals, only two canine cases in the trigeminal nerve [12] and subcutaneous tissue [5] have been described. In the present study, we describe the first case of feline malignant epithelioid schwannoma in the oral cavity.

An 8-year-old, intact female domestic short-hair cat was presented to the local private animal hospital with a 6-week history of swelling of the left maxillofacial area. A large gingival mass was observed at the left upper premolar to molar teeth. There was no previous medical or surgical history. The gingival mass was surgically removed and fixed in $10 \%$ buffered formalin. The mass was $3.0 \times 1.0 \times 0.6 \mathrm{~cm}$ in size and solid and firm with an irregular surface. At the cut surface, the mass was greyish-white and exhibited multinodular growth patterns (Fig. 1). At the first admission to hospital, metastasis was not observed in the thoracic and abdominal cavity by radiographic and computed tomography examina-

*Correspondence to: Park, C.-H., Associate Professor, Department of Veterinary Pathology, School of Veterinary Medicine, Kitasato University, 23-35-1 Higashi, Towada, Aomori 034-8628, Japan. e-mail: baku@vmas.kitasato-u.ac.jp

(C2014 The Japanese Society of Veterinary Science

This is an open-access article distributed under the terms of the Creative Commons Attribution Non-Commercial No Derivatives (by-nc-nd) License $<$ http://creativecommons.org/licenses/by-nc-nd/3.0/>. tions.

The mass was embedded in paraffin wax. Serial sections were cut at $3 \mu \mathrm{m}$ and stained with hematoxylin and eosin (HE), periodic acid-Schiff (PAS), Gomori's reticulin silver impregnation and for immunohistochemistry. The following primary antibodies were used: S-100 protein (Nichirei Biosciences, Tokyo, Japan), vimentin (Nichirei), glial fibrillary acidic protein antibody (GFAP, Nichirei), type IV collagen (Dako Japan, Kyoto, Japan), cytokeratin (CK) AE1/ AE3 (Nichirei), $\alpha$-smooth muscle actin (SMA, Dako Japan,), desmin (Dako Japan), calretinin (Zymed Laboratory, South San Francisco, CA, U.S.A.), PNL2 (Dako Japan) and MelanA (Dako Japan) (Table 1). The localization of the antigens was visualized with 3,3'-diaminobenzidine solution (Dako Japan). Finally, the sections were counterstained with hematoxylin. To investigate the proliferation rate of the tumor cell population, Ki-67 MIB-1 (Ki-67, Dako Japan) positive nucleoli were scored by counting at least 1,000 cells in representative $\times 400$ high-power fields. For electron microscopic examination, the formalin-fixed sample was cut into $1 \mathrm{~mm}^{3}$ blocks, post-fixed in $1 \%$ buffered osmium tetroxide and embedded in epoxy resin. Sections (about $70 \mathrm{~nm}$ thick) were stained with uranyl acetate and lead citrate and examined using a transmission electron microscope (H-7650, Hitachi, Tokyo, Japan).

Microscopically, at low-power view, the mass was not encapsulated and had grown invasively into the vertical margin in multinodular patterns (Fig. 2). The major components of the tumor were epithelioid cells arranged in densely packed sheets (Fig. 3). Tumor cells had large, centrally located, round to oval nuclei, and the nucleoli were usually single and prominent. The amount of eosinophilic cytoplasm in the tumor cells was variable, and the cytoplasmic borders were distinct. Occasionally, atypical cells with intranuclear eosinophilic pseudoinclusions were observed (Fig. 4). The mitotic index was 5 in $10 \times 400$ high-power fields. Hemorrhage and 

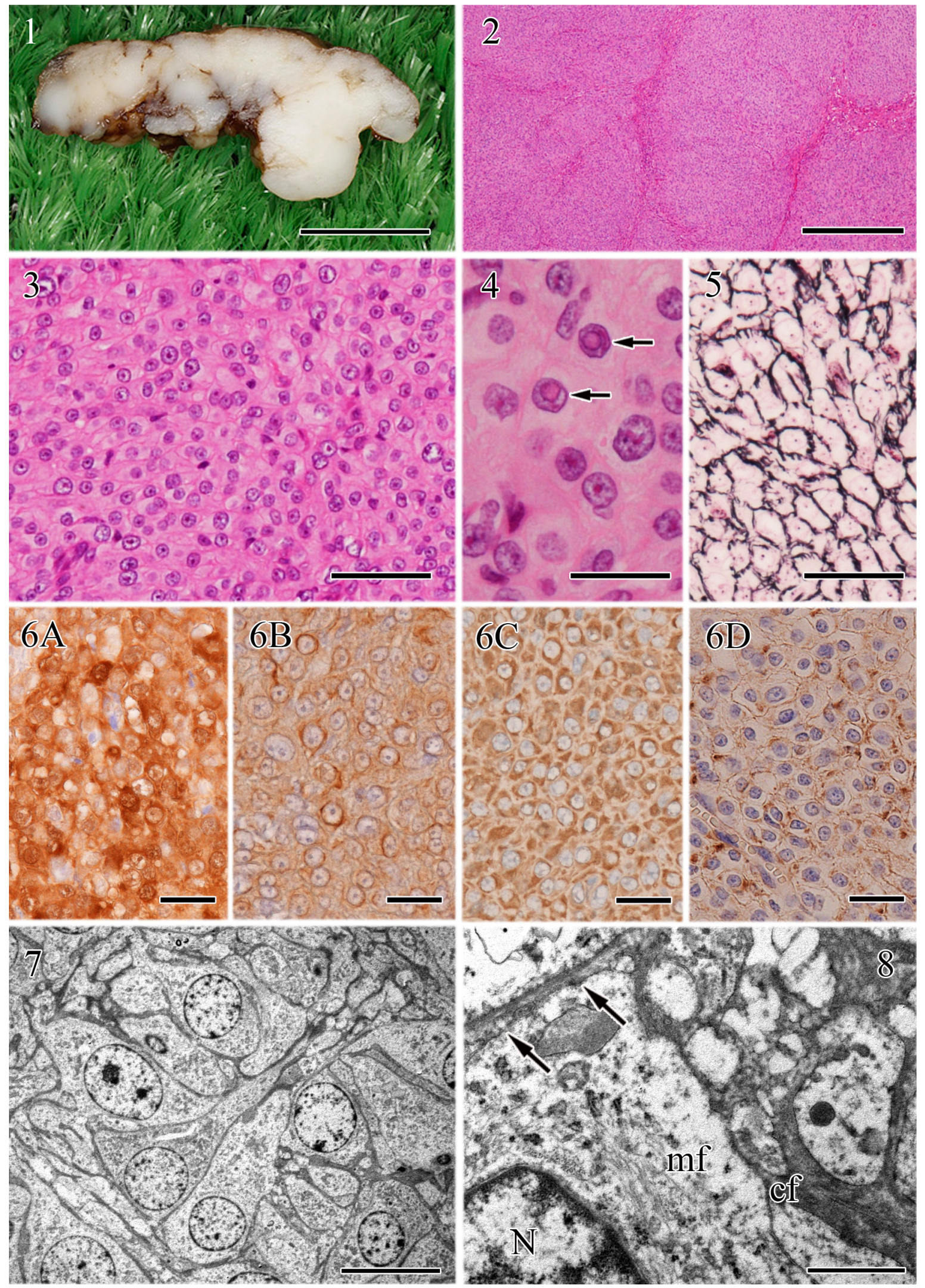
Table 1. Primary antibodies used for the immunohistochemical examination and results

\begin{tabular}{llllll}
\hline \multicolumn{1}{c}{ Antibody } & Clone & Source & Dilution & \multicolumn{1}{c}{ Antigen retrieval ${ }^{\mathrm{b})}$} & \multicolumn{1}{c}{ Results } \\
\hline Vimentin & V9 & Nichirei & Prediluted & MW, $170 \mathrm{~W}, 10 \mathrm{~min}$ & Positive, diffuse \\
S-100 & 4C4.9 & Nichirei & Prediluted & No treatment & Positive, diffuse \\
GFAP & GA5 & Nichirei & Prediluted & No treatment & Positive, diffuse \\
Type IV collagen & CIV22 & Dako & $1: 100$ & Pro-K, $37^{\circ} \mathrm{C}, 10 \mathrm{~min}$ & Positive, diffuse \\
Cytokeratin & AE1/ AE3 & Dako & $1: 50$ & Pro-K, $37^{\circ} \mathrm{C}, 10 \mathrm{~min}$ & Positive, scattered \\
SMA & 1A4 & Dako & $1: 1000$ & No treatment & Negative \\
Desmin & D33 & Dako & Prediluted & No treatment & Negative \\
Calretinin & DC8 & Zymed & Prediluted & AC, $121^{\circ} \mathrm{C}, 10$ min & Negative \\
PNL2 & PNL2 & Dako & Prediluted & AC, $121^{\circ} \mathrm{C}, 10$ min & Negative \\
Melan-A & A103 & Dako & $1: 300$ & AC, $121^{\circ} \mathrm{C}, 10$ min & Negative \\
Ki-67 & MIB-1 & Dako & Prediluted & MW, $750 \mathrm{~W}, 10 \mathrm{~min}$ & Positive, $35 \%$ \\
\hline
\end{tabular}

a) GFAP: glial fibrillary acidic protein, SMA: $\alpha$-smooth muscle actin. b) AC: autoclave, MW: microwave, Pro-K: Proteinase K.

focal necrosis were observed. PAS staining revealed glycogen granules in the cytoplasm of the tumor cells, and silver staining showed a delicate network of reticulin fibers around nests and along sheets of cells (Fig. 5). As shown in the other histological findings, a few individual mast cells were scattered throughout the tumor, and aggregations of small numbers of lymphocytes and neutrophils were observed.

Immunohistochemically, most of the tumor cells were strongly and diffusely positive for S-100 protein (Fig. 6A), GFAP (Fig. 6B) and vimentin (Fig. 6C), and CK AE1/AE3 positive cells were scattered. S-100 protein staining was found in the cytoplasm and nuclei of the tumor cells. By contrast, none of the tumor cells expressed melanoma-associated antigens (Melan-A, PNL2), muscle markers (desmin, SMA) or neuroendocrine markers (calretinin). Immunostaining for type IV collagen outlined a latticework of basement membrane material around individual cells (Fig. 6D) and groups of cells. The Ki-67 proliferation index was 35\% (Table 1).

Ultrastructurally, the polygonal tumor cells were separated by variable amounts of collagen fibers, and some cells showed long cytoplasmic processes (Fig. 7). Interdigitating cell processes were also observed. Cytoplasmic margins were well defined, and a basal lamina enveloped each cell. Nucleoli were large and irregular, and cytoplasmic organelles, such as mitochondria, rough endoplasmic reticulum, free ribosomes, glycogen granules and Golgi apparatus, were sparse. Occasionally, intracytoplasmic bundles of microfilaments and lysosome-like granules were seen (Fig. 8), but melanin granules, axons, myelin or microtubules were not observed.

Generally, schwannoma is an encapsulated nerve sheath tumor comprising two components: a highly ordered cellular component (Antoni A area) and a loose myxoid component (Antoni B area) [18]. Verocay bodies are rows of nuclear arrangements that are separated by anuclear zones of eosinophilic fibrillar material and are common in Antoni A areas; these are also seen in feline tumors [14]. Like a conventional schwannoma, epithelioid variants of schwannoma develop as a circumscribed and encapsulated mass, but Antoni $\mathrm{A}$ and B patterns are not observed in the epithelioid population as this case.

Differentiating between a benign and malignant epithelioid schwannoma is sometimes difficult, because both types have a similar morphological appearance. But, usually, benign epithelioid schwannoma shows superficial location, small size, low mitotic activity, insignificant cellular atypia, lack of necrosis and a high degree of schwannian differentiation [7]. The malignant epithelioid form is unusual, and the most characteristic appearance is densely packed multinodules of epithelioid cells arranged in a sheet-like pattern with large, round, pleomorphic nuclei with prominent nucleoli and the high mitotic index $[1,9,12]$.

The labeling indices of tumor proliferation markers, such as $\mathrm{Ki}-67$ and p53, differ between benign and malignant schwannomas. In humans, the mean $\mathrm{Ki}-67$ and p53 labeling indices for benign schwannoma were reported as $<5 \%$

Fig. 1. At the cut surface, the mass appears solid, firm and greyish-white. Bar $=1 \mathrm{~cm}$.

Fig. 2. At low-power view, the mass displays multinodular growth patterns. HE. Bar $=500 \mu \mathrm{m}$

Fig. 3. The major components of the tumor are epithelioid cells arranged in densely packed sheets. HE. Bar $=50 \mu \mathrm{m}$.

Fig. 4. Tumor cells shows nuclear atypia, and nucleoli are prominent. Occasionally, intranuclear eosinophilic inclusions (arrows) are observed in the atypical cells. HE. Bar $=25 \mu \mathrm{m}$.

Fig. 5. Individual tumor cells are surrounded by thin reticular fibers. Reticulin silver impregnation. Bar=25 $\mu \mathrm{m}$.

Fig. 6. (A-D). Most tumor cells are diffusely positive for S-100 (A), GFAP (B), vimentin (C) and type IV collagen (D). Immunostaining for type IV collagen outlines a latticework of basement membrane material around individual cells (D). Immunohistochemistry. Bar $=25 \mu \mathrm{m}$.

Fig. 7. Tumor cells are surrounded by variable amounts of stromal connective tissues, and some cells shows long cytoplasmic processes. Electron microscopy. Bar $=10 \mu \mathrm{m}$.

Fig. 8. Tumor cell is surrounded by variable amounts of collagen fibers (cf) and basal lamina (arrows). Intracytoplasmic bundles of microfilaments (mf) and lysosome-like granules are observed in the interdigitating cell processes. $\mathrm{N}=$ nucleus, Electron microscopy. Bar=1 $\mu \mathrm{m}$. 
and $<1 \%$, whereas those for malignant epithelioid schwannoma were $5-65 \%$ and $5-100 \%$, respectively [6]. In the present case, the Ki-67 proliferation index was $35 \%$. The ranges of the $\mathrm{Ki}-67$ and p53 labeling indices in these reports are wide, and the expression of these markers has not been investigated in feline epithelioid schwannoma. However, it was considered that the present results of the immunohistochemistry of Ki-67 suggested malignant properties.

In the present case, the tumor cells sometimes had intranuclear eosinophilic inclusions. These intranuclear inclusions are found in schwannomas and in other tumors including meningiomas [20], paragangliomas [4], pheochromocytomas [4] and pituitary tumors [19]. Intranuclear inclusions in these tumors are formed by cytoplasmic invagination and comprise cytoplasmic organelles, such as rough endoplasmic reticulum, the Golgi apparatus and secretory granules $[4,19]$. To our knowledge, intranuclear inclusions have not been reported in malignant epithelioid schwannoma in cats. Therefore, further data collection is needed to understand better the relationship between the intranuclear inclusions and malignancy of epithelioid schwannoma in cats.

The most common malignant tumor of the oral cavity in dogs is melanoma [11]. By contrast, oral melanoma is uncommon, and oral amelanotic melanoma is extremely rare in cats [10]. Immunohistochemical analysis shows that both types of oral melanoma strongly express Melan-A and S-100 protein. In the present case, most of the tumor cells stained positively for S-100 protein, GFAP, vimentin and type IV collagen, but all cells were negative for melanomaassociated antigens. In addition, the most characteristic findings in the melanoma, such as melanin pigments, lamellipodia, filopodia and evidence of ruffling and endocytosis, are not observed by electron microscopy $[2,16]$. Therefore, the possibility of a tumor originating from melanocytes was excluded from the differential diagnosis.

Distant metastasis and spread of malignant epithelioid schwannomas to regional lymph nodes have been reported in humans, but the rate of metastasis is generally low $[8,9]$. In the present case, no evidence of additional tumor growth, invasion or metastasis was found during the 14-month follow-up, and we concluded that this tumor had a low malignancy compared with oral malignant melanoma and that the prognosis was good after complete surgical excision.

\section{REFERENCES}

1. Alvira, M. M., Mandybur, T. K. and Menefee, M. G. 1976. Light microscopic and ultrastructural observations of a metastasizing malignant epithelioid schwannoma. Cancer 38: 1977-1982. [Medline] [CrossRef]

2. Cheville, N. F. 1994. Secretory granules. pp. 246-251. In: U1trastructural Pathology, 1st ed. (Cheville, N. F. ed), Iowa State University Press, Ames.

3. Chijiwa, K., Uchida, K. and Tateyama, S. 2004. Immunohistochemical evaluation of canine peripheral nerve sheath tumors and other soft tissue sarcomas. Vet. Pathol. 41: 307-318. [Medline] [CrossRef]

4. DeLellis, R. A., Suchow, E. and Wolfe, H. J. 1980. Ultrastructure of nuclear "inclusions" in pheochromocytoma and paragan- glioma. Hum. Pathol. 11: 205-207. [Medline] [CrossRef]

5. García, P., Sánchez, B., Sánchez, M. A., González, M., Rollán, E. and Flores, J. M. 2004. Epithelioid malignant peripheral nerve sheath tumor in a dog. J. Comp. Pathol. 131: 87-91. [Medline] [CrossRef]

6. Kindblom, L. G., Ahldén, M., Meis-Kindblom, J. M. and Stenman, G. 1995. Immunohistochemical and molecular analysis of p53, MDM2, proliferating cell nuclear antigen and Ki67 in benign and malignant peripheral nerve sheath tumors. Virchows Arch. 427: 19-26. [Medline] [CrossRef]

7. Kindblom, L. G., Meis-Kindblom, J. M., Havel, G. and Busch, C. 1998. Benign epithelioid schwannoma. Am. J. Surg. Pathol. 22: 762-770. [Medline] [CrossRef]

8. Laskin, W. B., Weiss, S. W. and Bratthauer, G. L. 1991. Epithelioid variant of malignant peripheral nerve sheath tumor (malignant epithelioid schwannoma). Am. J. Surg. Pathol. 15: 1136-1145. [Medline] [CrossRef]

9. Lodding, P., Kindblom, L. G. and Angervall, L. 1986. Epithelioid malignant schwannoma: A study of 14 cases. Virchows. Arch. A Pathol. Anat. Histopathol. 409: 433-451. [Medline] [CrossRef]

10. Patnaik, A. K. and Mooney, S. 1988. Feline melanoma: a comparative study of ocular, oral, and dermal neoplasms. Vet. Pathol. 25: 105-112. [Medline] [CrossRef]

11. Pulley, L. T. and Stannard, A. A. 1990. Melanocytic tumor. pp. 75-82. In: Tumors in Domestic Animals, 3rd ed. (Moulton, J. E. ed.), University of California Press, Berkeley.

12. Pumarola, M., Anor, S., Borras, D. and Ferrer, I. 1996. Malignant epithelioid schwannoma affecting the trigeminal nerve of a dog. Vet. Pathol. 33: 434-436. [Medline] [CrossRef]

13. Schöniger, S., Valentine, A., Fernandez, A. and Summers B. A. 2011. Cutaneous schwannomas in 22 horses. Vet. Pathol. 48: 433-442. [Medline] [CrossRef]

14. Schulman, F. Y., Johnson, O. T., Facemire, P. R. and FanburgSmith, J. C. 2009. Feline peripheral nerve sheath tumor: Histologic, immunohistochemical, and clinicopathologic correlation (59 tumors in 53 cats). Vet. Pathol. 46: 1166-1180. [Medline] [CrossRef]

15. Tanimoto, T. and Ohtsuki, Y. 1992. A solitary schwannoma in the cecum of a cow. Vet. Pathol. 29: 81-83. [Medline] [CrossRef]

16. van der Linde-Sipman, J. S., de Wit, M. M., van Garderen, E., Molenbeek, R. F., van der Velde-Zimmermann, D. and de Weqer, R. A. 1997. Cutaneous malignant melanomas in 57 cats: identification of (amelanotic) signet-ring and balloon cell types and verification of their origin by immunohistochemistry, electron microscopy, and in situ hybridization. Vet. Pathol. 34: 31-38. [Medline] [CrossRef]

17. Weiss, S. W. and Goldblum, J. R. 2001. Epithelioid malignant peripheral nerve sheath tumor (epithelioid malignant schwannoma). pp. 1235-1240. In: Enzinger and Weiss's Soft Tissue Tumors, 4th ed. (Weiss, S. W. and Goldblum, J. R. eds.), Mosby, St Louis.

18. Weiss, S. W. and Goldblum, J. R. 2001. Schwannoma (neurilemoma). pp. 1146-1160. In: Enzinger and Weiss's Soft Tissue Tumors, 4th ed. (Weiss, S. W. and Goldblum, J. R. eds.), Mosby, St Louis.

19. Yang, S. W., Yang, K. M., Kang, H. Y. and Kim, T. S. 2003. Intranuclear cytoplasmic pseudoinclusions in pituitary adenomas. Yonsei Med. J. 44: 816-820. [Medline]

20. Yoshida, T., Hirato, J., Sasaki, A., Yokoo, H., Nakazato, Y. and Kurachi, H. 1999. Intranuclear inclusions of meningioma associated with abnormal cytoskeletal protein expression. Brain Tumor Pathol. 16: 86-91. [Medline] [CrossRef] 